\title{
Adverse possession and unadministered estates: an unfair solution to a redundant Irish problem?

\author{
UNA WOODS
}

University of Limerick

\section{Introduction}

$I^{\prime}$ $\mathrm{t}$ is frequently asserted that the doctrine of adverse possession performs a valuable social function in Ireland by allowing the ownership of land forming part of an unadministered estate to be updated many years after the death of the owner. More specifically, it is argued that this role is particularly important in rural Ireland where, historically, will-making was uncommon, emigration was widespread and grants of representation were rarely extracted in relation to small farms. ${ }^{1}$ The typical scenario involved the death of the registered owner of a farm ${ }^{2}$ with the result that his children became entitled to the land as co-owners under the rules governing intestacies. However, only one (or some) of his children remained in possession of the farm for 12 years or more, while the others left to work and live elsewhere. In the meantime, the deceased farmer's estate remained unadministered. On the expiry of the limitation period, a Land Registry application could be made by the child in possession, frequently the eldest son, pursuant to s 49 of the Registration of Title Act 1964 to register him as the new proprietor on the basis of his adverse possession. ${ }^{3}$ A s 49 application avoids the inconvenience and expense of extracting multiple grants if there was more than one death on the title or the need to obtain numerous consents to a deed of family arrangement for the purposes of releasing the intestate shares of the applicant's siblings.

The role played by the doctrine in this context was acknowledged in the Oireachtas debates which preceded the enactment of s 126 of the Succession Act 1965 which reduced the limitation period for claims in respect of the estate of a deceased person from 12 years to six years. ${ }^{4}$ This amendment was clearly intended to promote reliance on the doctrine to resolve a problem perceived to be peculiar to rural Ireland at the time.

1 See A Lyall (with A Power), Land Law in Ireland 3rd edn (Round Hall 2010) 990; J C W Wylie, Irish Land Law 5th edn (Bloomsbury Professional 2013) para 23.42; R A Pearce, 'Adverse Possession by the Next-of-Kin of an Intestate' (1987) 5 Irish Law Times 281; Law Reform Commission, Report on Reform and Modernisation of Land Law and Conveyancing Law (LRC 74 2005) 331-32.

2 Nearly all agricultural land in Ireland is registered in the Land Registry as tenant farmers who purchased their holdings under the Land Purchase Acts were required to apply for compulsory first registration pursuant to the Local Registration of Title (Ireland) Act 1891.

3 Keane J referred to this practice in Gleeson v Feehan [1997] ILRM 522, 539.

4215 Dail Debates col 2027. 
More recently, in its third-party submission to Grand Chamber in Pye, ${ }^{5}$ the government of Ireland referred to the role played by the doctrine in facilitating the intergenerational transfer of farms in Ireland ${ }^{6}$ and argued that the doctrine represented a proportionate means of achieving this and other legitimate aims, justifying any potential interference with the property rights of owners. ${ }^{7}$ In sharp contrast, in England and Wales a co-owner under an unadministered estate is absolutely precluded from relying on the doctrine and it has been argued that it would be unfair to allow a strong-willed occupying member of the family to obtain title by adverse possession as a result of the generous attitude of other members of the family. ${ }^{8}$

Adverse possession between co-owners traditionally gave rise to theoretical difficulties as one of the basic tenets of co-ownership is unity of possession; therefore possession by one co-owner was deemed to be possession by all of them. Before the enactment of the Real Property Limitation Act 1833 it was only possible for a co-owner who could prove that he had ousted the other co-owners to rely on the doctrine against them. The First Report of Commissioners on Real Property published in 1829 indicated that it would be desirable to permit a finding of adverse possession between co-owners without proof of an ouster. Section 12 of the Real Property Limitation Act 1833 gave effect to this recommendation and provided that, if a co-owner was in possession of more than his share of the land for his own benefit, such possession would not be deemed to be the possession of the other co-owners. ${ }^{9}$ While this rule is re-enacted by s 21 of the Irish Statute of Limitations $1957,{ }^{10}$ the English law on this issue diverged with the enactment of the Law of Property Act 1925 and the current position in England is that adverse possession between co-owners is absolutely precluded. ${ }^{11}$

If the co-ownership entitlements arise under an unadministered estate, the operation of the doctrine becomes even more complicated as ownership vests for the meantime in the deceased's personal representatives or the Irish High Court/English Public Trustee. ${ }^{12}$ Occasionally, a personal representative, who is also entitled to a share in the estate, takes possession of the land for the limitation period. In this context, the implications of two other rules must be considered: the personal representative is deemed to hold the estate on trust for those entitled to it under the will or intestacy rules ${ }^{13}$ and no limitation period

5 Third-party submission by the Irish government, 23 August 2006. See JA Pye (Oxford) Ltd v UK (2008) 46 EHRR 45.

6 Ibid para 13.

7 Ibid para 24.

8 G Miller, 'The Administration of Estates and Adverse Possession' (2000) 150 New Law Journal 940, 946.

9 Legislation equivalent to the Real Property Limitation Act 1833 was never enacted in the USA which has retained the requirement for an ouster to the present day. To rely on the doctrine of adverse possession, a coowner must be in a position to prove a repudiation of the co-ownership relationship, notice of such repudiation to the co-owner out of possession and possession after such repudiation and notice for a time sufficient to satisfy the relevant statute of limitations. See W A Knight, 'The Adverseness of Possession to Fractional Interests' (1957) 9 Baylor Law Review 168; S O’Moore, 'Adverse Possession Between Cotenants: The Requirement of Actual Notice' (1971) 42 Mississippi Law Journal 137; S F Kurtz and H Hovenkamp, Cases and Materials on American Property Law (West Publishing Co 1987) 186-88.

10 Note that s 21 of the 1957 Act, although mentioned in the pleadings, appears to have been ignored by the court in a recent case, Moore v Moore [2010] IEHC 462.

11 Limitation Act 1980, Schedule 1, para 9.

12 Succession Act 1965, ss 10(1) and 13; Administration of Estates Act 1925, ss 1(1) and 9(1). Note that in England before 1 July 1995 the property of a deceased intestate vested in the Probate Judge (i.e. the President of the Family Division); s 14 of the Law of Property (Miscellaneous Provisions) Act 1994 substituted a new s 9(1) into the Administration of Estates Act 1925 which vests such property in the Public Trustee.

13 Succession Act, s 10(3); Administration of Estates Act 1925, s 33(1). 
applies to actions to recover trust property in the possession of a trustee. ${ }^{14}$ Under Irish law, a personal representative is not deemed to be a 'trustee' for the purposes of the running of the limitation period ${ }^{15}$ and so he or she can rely on the doctrine to extinguish the claims of the deceased owner's successors. However, under English law the definition of a 'trustee' includes a personal representative ${ }^{16}$ and therefore a personal representative may not rely on the doctrine of adverse possession against those with entitlements to the estate.

Recently, concerns have been expressed in law reform circles in Ireland and elsewhere in relation to the fairness of the doctrine of adverse possession, in particular the doctrine's limitations in protecting owners against the danger of inadvertently losing title by adverse possession and the extent to which the doctrine permits squatters who know that they do not own the land (i.e. deliberate or 'bad faith' squatters) to acquire title. In England and Wales, the qualified veto system of adverse possession introduced by the Land Registration Act 2002 which applies to land which has been registered in the Land Registry purported to address both concerns. Additional protection is conferred on the registered owner who may veto an adverse possession application, but the qualifications to the veto system preserve the operation of the doctrine for certain adverse possessors in the interests of fairness (for example, a good faith adverse possessor of boundary land). ${ }^{17}$ In 2005 , the Irish Law Reform Commission proposed certain reforms to the law on adverse possession which imposed a mandatory requirement for a court application and restricted the operation of the doctrine to certain categories of claimant. An attempt was made to preserve the existing role played by the doctrine in the context of unadministered estates by conferring jurisdiction on the court to make an order vesting ownership in the applicant where the adverse possession application 'relates to land comprised in a deceased person's estate and it is reasonable to assume that an order in favour of the applicant would accord with the deceased's wishes'. ${ }^{18}$ 'These Irish law reform proposals were ultimately jettisoned in response to critical submissions made to the Irish government by the Law Society's Conveyancing Committee, mostly related to the workability and increased costs involved in the administration of the proposed scheme. ${ }^{19}$ However, the Irish Law Reform Commission plans to revisit the matter of reform in this area of law in the future. In this event, the introduction of a qualified veto system of adverse possession is likely to be considered for Ireland. A discussion of the substantive arguments in favour of the introduction of such a reform has taken place elsewhere. ${ }^{20}$ The aim of this article, however, is to consider whether the doctrine of adverse possession should continue to play the same role in the context of unadministered estates. If the introduction of a qualified veto system of adverse possession is proposed for Ireland, it will be necessary to consider whether it should be tempered by a qualification to preserve its existing role in this particular context. This article discusses whether such a qualification is necessary in the interests of fairness to address a prevailing social problem. It concludes that the particular

14 Statute of Limitations 1957, s 44; Limitation Act 1980, s 21.

15 Succession Act 1965, s 123.

16 S 38(1) of the Limitation Act 1980 adopts the definition set out by s 68(1)(17) of the Trustee Act 1925.

17 The Law Commission also claimed that these reforms were essential to ensure the compatibility of the doctrine of adverse possession with title registration principles. For a critique of this justification for the reforms, see U Woods, 'The English Law on Adverse Possession: A Tale of Two Systems' (2009) 38(1) Common Law World Review 27, 31-38.

18 Law Reform Commission (n 1) 329-30.

19 See U Woods, 'The Position of the Owner under the Irish Law on Adverse Possession' (2008) 30 Dublin University Law Journal 298, 300-03.

20 For such a discussion, see U Woods, 'The Irish Law on Adverse Possession: The Case for a Qualified Veto System', PhD thesis, Queen's University Belfast, 2015. 
problem of deceased farmers' estates remaining unadministered has become redundant and it is critical of the result achieved by the doctrine of adverse possession in the context of unadministered estates.

Parts 1 and 2 of this paper trace the historical development of this technically difficult area of law in England and in Ireland. While the current English position achieves a sensible result, it appears to have happened inadvertently and not as a result of any considered policy decision. In contrast, the traditional policy justification for the Irish position has been accepted on numerous occasions without any consideration of the fairness of the result, particularly in a non-agricultural context. Part 3 of this paper, therefore, examines whether the Irish position is justified in modern times. The paper concludes by discussing how the adoption of a qualified veto system of adverse possession could confer added protection on those with co-ownership entitlements under unadministered estates, but also preserve the doctrine to restore land to the market if such interests have been abandoned and facilitate certain informal transmissions on death.

\section{The development of the law in England}

In England and Wales, before the Law of Property Act 1925 came into force, many cases were heard which involved one or more co-owners relying on s 12 of the 1833 Act to claim the benefit of the doctrine of adverse possession where they had possessed the property to the exclusion of the other co-owners. ${ }^{21}$ In more recent times, the Judicial Committee of the Privy Council has heard a number of cases on appeal from Commonwealth jurisdictions where the law on this issue has remained unchanged. ${ }^{22}$

The entry into force of the Law of Property Act 1925 on 1 January 1926 brought about a fundamental change to the legal structure of co-ownership in England and Wales. From that date the legal title to co-owned property could only be held by joint tenants and a statutory trust for sale was imposed in all cases of co-ownership where such a trust was not expressly created. This resulted in many co-owners holding the land on trust for sale for themselves as equitable tenants in common, or joint tenants; it also brought about an inadvertent change in the application of the doctrine of adverse possession, as was highlighted in Re Landi. ${ }^{23}$ The circumstances of that case involved one tenant in common receiving the entire rent in relation to the co-owned premises for over 20 years from the end of 1923 onwards. Sir Wilfred Greene MR pointed out that the 1925 Act converted both tenants in common into trustees, although they were also beneficiaries. He held that s 12 of the 1833 Act no longer applied as it contemplated a co-ownership relationship which did not involve a trust. He noted: 'The language is quite inapt to cover the case of one of two trustees who are also their own beneficiaries.' Sir Wilfred Greene MR concluded that a trustee in possession or receiving rents and profits can never be regarded as doing so for his own benefit and, therefore, the limitation period cannot run in his favour.

The approach adopted in Re Landi gave rise to an inconsistency as a beneficial coowner who was not a trustee ${ }^{24}$ could bar the title of the other beneficiaries through adverse possession. This lacuna was closed by s 7(5) of the Limitation Act 1939 which made it clear that one beneficial co-owner cannot be in adverse possession against another, regardless of the location of the legal estate. This provision was re-enacted by para 9, Schedule 1 of the Limitation Act 1980. Although co-owned land is now regarded

21 See Paine v Ryder (1857) 24 Beav 151; Thornton v France [1897] 2 QB 143; Glyn v Howell [1909] 1 Ch 666.

22 See e.g. Paradise Beach and Transportation Co Ltd v Price-Robinson [1968] AC 1072.

23 [1939] Ch 828.

24 An express trust for sale may have been created or the statutory trust for sale may have vested legal ownership in the Probate Judge or the Public Trustee. 
as being held on a trust of land rather than a trust for sale, ${ }^{25}$ para 9 provides that, where such land is in the possession of a person entitled to a beneficial interest in the land (and not being a person solely or absolutely entitled to the land), no right of action to recover the land shall be treated as accruing during that possession to any person in whom the land is vested as trustee or to any other person entitled to a beneficial interest in the land.

In Earnshaw v Hartley, 26 the Court of Appeal ruled that para 9 also applied in the context of an unadministered estate to prevent time running where one intestate successor possesses the property to the exclusion of others entitled to an intestate share. In that case a son had remained on the farm after his mother died intestate in 1983 . He was later joined by his wife, the defendant, and in 1995 the son died. His mother had also been survived by three daughters who obtained letters of administration to their mother's estate in 1998 and sought various forms of relief, including a declaration as to the beneficial ownership and an order for sale. The defendant alleged that the daughters' entitlements had been extinguished by her husband's and her own successive adverse possession of the farm. Counsel for the defendant argued that para 9 did not apply before the grant of administration was extracted as the farm was vested in the President of the Family Division at that time and it was not held on a trust for sale. Nourse LJ refused to apply this literal interpretation to para 9 and stated that, although technically the farm was not held on trust for sale while it was vested in the President of the Family Division, ${ }^{27}$ it was presumptively so held; it would be artificial to distinguish between the position before and after the grant of administration. In the same vein, counsel for the defendant argued that the siblings did not have a beneficial interest in the land or the proceeds of sale, but only a right to require the mother's estate to be duly administered and to receive a quarter share of the net estate on completion of the administration. Nourse LJ held that it would be equally artificial to suggest that the siblings did not have an interest in the farm which was sufficient for the purposes of para 9.28

As has already been mentioned, a personal representative is deemed to be a 'trustee' for the purposes of the Limitation Act $1980^{29}$ and s 21 provides that no period of limitation shall apply to an action by a beneficiary to recover trust property in the possession of a trustee. Therefore, a beneficial co-owner in possession who has extracted a grant of representation will be prevented from relying on the doctrine on two grounds: first, because of his or her position as a trustee and second, because of his or her position as a beneficial co-owner.

Even if the beneficial co-owner in possession has not extracted a grant, the decision in James $v$ Williams $^{30}$ highlights that he could be deemed to be an executor de son tort on the basis that he had intermeddled with the estate of the deceased. Although an executor de son tort does not come within the definition of a personal representative, ${ }^{31}$ if he is also deemed to be a constructive trustee, ${ }^{32}$ which happened in James $v$ Williams, s 21 will apply to prevent time running in his favour. The circumstances in James $v$ Williams were similar

25 The Trusts of Land and Appointment of Trustees Act 1996 replaced the trust for sale with a simple trust of land.

26 [2000] Ch 155.

27 Note that this role has been performed by the Public Trustee since 1 July 1995, see n 12 above.

28 See Earnshaw (n 26) 161.

29 See n 16 above.

30 [2000] Ch 1.

31 See Trustee Act 1925, s 68(1)(9).

32 A trustee is defined as including a constructive trustee by s 68(1)(17) of the Trustee Act 1925. 
to those in Earnshaw $v$ Hartley. ${ }^{33}$ On the intestate death of the owner, his wife became entitled to the beneficial interest in the family home, but she took no steps to administer his estate. She died intestate in 1972 and the property was held on statutory trust for sale for her three adult children: a son, William junior; a daughter, Thirza; and another daughter, the plaintiff. The plaintiff had moved out of the property when she got married and only visited from time to time. After the mother died, the plaintiff's siblings made it clear to her that she was unwelcome at the family home and she became estranged from them. From that point onwards, William Junior behaved as if he owned the property. He left the property to Thirza when he died in 1993 and when Thirza died in 1995 it was left to her child, the defendant. The plaintiff sought a declaration that she was entitled to a one-third share in the property and an order for the sale of the property. The defendant contended that her claim was statute-barred.

It is unclear why the plaintiff failed to plead para 9 which prevents adverse possession between beneficial co-owners. ${ }^{34}$ Instead, the parties focused on whether the son, as an executor de son tort, was also a constructive trustee; if he was, the parties accepted that the limitation period could not begin to run in his favour. Counsel for the defendant seemed to accept without question that his behaviour qualified as that of an executor de son tort. The court relied heavily on an article published in $1974^{35}$ in which the author, Hinks, maintained that anyone who takes possession of the property of a deceased person without the permission of the personal representatives or the court is an executor de son tort. ${ }^{36}$ Hinks noted that an executor de son tort can rely on the doctrine of adverse possession unless he or she is also a constructive trustee. ${ }^{37}$ He pointed out that there would appear to be no justification for imposing a constructive trust where the executor de son tort is a complete stranger save in the most exceptional circumstances. ${ }^{38}$ This makes sense as otherwise it would never be possible to acquire title by adverse possession against land which formed part of the estate of a deceased owner. ${ }^{39}$ On the other hand, Hinks argued that, where a brother seeks to establish title by adverse possession against his adult siblings, there would appear to be every justification for imposing a constructive trust. 40 The court concluded that the circumstances of the case gave rise to such a constructive trust. The brother knew he was not solely entitled to the property when he took possession of it and it would be inequitable to allow him to take advantage of his decision not to take out letters of administration. Therefore, he was under an equitable duty to hold it for himself and his sisters on constructive trust.

33 Both cases are discussed by Miller (n 8) and Z Robertson, 'Intestate Succession and Adverse Possession' (2001) Private Client Business 40.

34 It is interesting, however, that the conversation in which she was told she was not welcome would have given rise to an ouster under the law which prevailed before the introduction of s 12 of the Real Property Act 1833. In Earnshaw (n 26), Nourse LJ commented that the impact of s 7(5) of the 1939 Act, and subsequently para 9 , was the re-introduction of the doctrine of non-adverse possession amongst co-owners of land which had applied before the enactment of s 12 of the Real Property Act 1833. However, before 1833, adverse possession was possible between co-owners if an ouster could be proved; since the enactment of the 1939 Act it is clear that adverse possession between co-owners is never possible.

35 F Hinks, 'Executors de Son Tort and the Limitation of Actions' [1974] Conveyancer and Property Lawyer 176.

36 Ibid 184.

37 Ibid 182.

38 Ibid 184.

39 Such an approach is clearly not envisaged by s 26 of the Limitation Act 1980 which allows time to run against a deceased person's estate, regardless of whether a personal representative has been appointed.

40 Hinks (n 35) 185. 
Jourdan and Radley-Gardner argue that the decision in James $v$ Williams was per incuriam in relation to two matters. ${ }^{41}$ First, it was made in ignorance of para 9 and should simply have been decided on the basis that the brother was a beneficial co-owner and so the limitation period could not have run in his favour. Second, the attention of the court was not drawn to an earlier decision of the Court of Appeal in Pollard v Jackson ${ }^{42}$ which decided that a squatter who took possession of a flat, knowing of the owner's death, was neither an executor de son tort nor a constructive trustee. There seems to be a divergence of opinion on whether simply taking possession of property is sufficient to make a person an executor de son tort. Assuming that it is sufficient, the circumstances in Pollard can be clearly distinguished from those in Earnshaw $v$ Hartley as the squatter in Pollard was a stranger and so would not have fallen within the category of circumstances which Hinks described as giving rise to a possible constructive trust. It should be mentioned, at this point, that if the Law Commission recommendations in its Report on the Limitation of Actions $^{43}$ are implemented, it will be possible for a trustee or a personal representative to claim the benefit of the limitation period against a beneficiary. ${ }^{44}$ This would stunt the development of James $v$ Williams as an authority in this area and a beneficial co-owner out of possession would be restricted to relying on para 9.

To summarise, in England and Wales, in all circumstances where co-ownership entitlements arise under a will or on intestacy, it is impossible for either a personal representative or someone with entitlements under an unadministered estate to benefit from the doctrine. Only a stranger to the title can benefit. Although the changes to the doctrine's application between co-owners, initially brought about by the 1925 legislation, may not have been the result of a deliberate policy decision, the position appears to have been accepted ${ }^{45}$ and even embraced by commentators. ${ }^{46}$

\section{THE IMPACT OF RECENT REFORMS}

The qualified veto, introduced by the Land Registration Act 2002 to govern adverse possession of registered land, may be exercised by the registered owner and other specified persons. ${ }^{47}$ If the registered owner is deceased, she will obviously not be in a position to exercise a veto, although her personal representative may register as a person entitled to be notified of any adverse possession applications under rule 194.48 If a stranger to the title was in adverse possession before the death of the registered owner, it behoves a personal representative to act quickly to ensure that the veto is not lost. If an adverse possession application is lodged after the death, but before the personal

41 S Jourdan and O Radley-Gardner, Adverse Possession 2nd edn (Bloomsbury Professional 2012) para 31.13.

42 (1994) 67 P \& CR 327.

43 Law Commission, Report on the Limitation of Actions No 270 (2001).

44 Ibid paras 4.106 and 4.125 .

45 This writer is not aware of any calls for a return to the position under s 12 of the 1833 Act.

46 Miller has argued that it would be unfair to allow a co-owner to benefit from the doctrine of adverse possession; see text accompanying (n 8) above.

47 Land Registration Act 2002, Schedule 6, para 2, requires the registrar to give notice of an adverse possession application to the registered proprietor of the estate, the registered proprietor of any charge, the registered proprietor of any superior registered estate (if the estate is leasehold), any person who is registered in accordance with rules as a person to be notified under this paragraph and other persons as rules may provide. Rule 194 of the Land Registration Rules 2003 provides that any person who can satisfy the registrar that he or she has an interest in a registered estate in land that would be prejudiced by the registration of the adverse possessor as proprietor of that estate may apply to be registered as a person to be notified under Schedule 6, para 2.

48 I am grateful to Mr Patrick Milne, Assistant Land Registrar with the English Land Registry, for discussing the notice requirements in this area with me. Any errors are my own. 
representative has had a chance to administer the estate or register under rule 194, it is likely that no one will be in a position to exercise the veto. The legislative intention may have been to restrict the added protection of the veto to those who act quickly to update the register following a disposition. However, it is submitted that the current rules have the potential to operate quite harshly following a death on title where the registration gap before the registration of the transmission may be longer due to the delays inherent in extracting a grant of representation. It should be noted that the beneficiaries under the unadministered estate are not in a position to protect themselves, as an application by such beneficiaries to be notified of adverse possession applications pursuant to rule 194 would probably be rejected by the registrar on the basis that such beneficiaries have no interest in the land. ${ }^{49}$

This paper considers whether adverse possession is possible between beneficiaries under an unadministered estate and the Land Registration Act 2002 does not change the pre-existing law which prevented time running in these circumstances. As the law currently stands in England and Wales, neither a trustee nor a beneficiary can benefit from the doctrine of adverse possession against another beneficiary. However, time may run against a trustee if the beneficiary is solely entitled. ${ }^{50}$ In its discussion of the exceptions to the veto system introduced by the 2002 Act, the Law Commission noted that a person solely entitled by will or intestacy would qualify as a person entitled to be registered as proprietor 'for some other reason'. ${ }^{51}$ This exception would be relevant if the personal representative had registered himself as the owner and would prevent such a personal representative from vetoing an application by a person solely entitled who can also prove adverse possession of the land for at least 10 years.

\section{AlteRnATIVE REMEDIES}

Although a person entitled to a co-owner's share in land pursuant to an unadministered estate is precluded from relying on the doctrine of adverse possession, if she can prove that the deceased owner represented to her that she would have some interest in the land and she relied on that representation to her detriment, she may be entitled to a remedy under the doctrine of proprietary estoppel. ${ }^{52}$ The court may even order that the property be transferred into her sole name. Recent restrictions imposed on this doctrine in the context of informal commercial transactions ${ }^{53}$ do not appear to have impacted on the doctrine's potential to provide a remedy in the context of an informal testamentary

49 A beneficiary under a will or on intestacy is generally regarded as having no legal or equitable interest in the unadministered assets of the deceased's estate: see Commissioner of Stamp Duties (Queensland) $v$ Livingston [1965] AC 694. It is occasionally argued that a beneficiary entitled under a specific bequest or devise takes an equitable interest in the subject matter of the gift at the testator's date of death: see IRC $v$ Hawley [1928] $1 \mathrm{~KB} 578$.

50 Limitation Act 1980, para 9, Schedule 1.

51 See Law Commission, Land Registration for the Twenty-First Century: A Conveyancing Revolution No 271 (2001) para 14.43.

52 See Gillet v Holt [2001] Ch 210; Re Basham [1986] 1 WLR 1498; Wayling v Jones (1995) 69 P \& CR 170.

53 See Yeoman's Row Management Ltd v Cobbe [2008] UKHL 55; M Dixon, 'Proprietary Estoppel - The Pendulum Swings Again?'[2009] Conveyancer and Property Lawyer 141; B McFarlane, 'The Protection of PreContractual Reliance: A Way Forward?' (2010) 10(1) Oxford University Commonwealth Law Journal 95. 
disposition. ${ }^{54}$ Alternatively, a child of the deceased owner may be in a position to apply for provision under the Inheritance (Provision for Family and Dependants) Act 1975, if he or she can prove that the will or intestacy rules failed to make reasonable provision for his or her maintenance. ${ }^{55}$ Such a claim must be brought within six months of the extraction of the grant of representation, although the court has discretion to extend this deadline. ${ }^{56}$

Where only one person with entitlements under an unadministered estate goes into possession, the others may be content to disclaim their interests or be bought out. ${ }^{57}$ If the land has increased in value since this person went into possession, that individual's bargaining power will have decreased. As one court succinctly put it, often only the 'smell of oil' in previously valueless land rekindles an interest in its ownership. ${ }^{58}$ If such negotiations fail, a personal representative or any of the beneficial co-owners may apply for an order for the sale of the property and the division of the proceeds between them. ${ }^{59}$ If the other beneficial co-owners have abandoned the land and cannot be traced, it may be possible to register the remaining co-owner as the sole owner pursuant to a Benjamin Order or by taking out missing beneficiary insurance. Alternatively, the land may be sold by the personal representative in the course of administration, ${ }^{60}$ or by the trustees of the land if it has already been vested in the co-owners by means of an assent. In the context of a sale by the trustees of the land, provided the statutory preconditions in relation to overreaching are met, ${ }^{61}$ the purchaser will take the land free of the interests of any coowners which attach instead to the capital money. Although adverse possession is often regarded as playing an essential role in restoring abandoned land to the market, the doctrine is unnecessary in this particular context as its release onto the market is facilitated by either the powers of the personal representative or the overreaching mechanism. The absent co-owners' share of the sale proceeds may be preserved for them in a separate account or, if missing beneficiary insurance or a Benjamin Order were obtained, it may be distributed to the remaining co-owner.

\section{The development of the law in Ireland}

A number of issues which had obfuscated the law in this area have recently been clarified by Irish case law and legislation. First of all, where only one or some of the persons entitled to an intestate share took or remained in possession after the death of the owner, doubts arose in relation to the impact of their entitlements as next-of-kin on the operation of the doctrine of adverse possession. A strong line of early authority

54 As demonstrated by the recent House of Lords' decision in Thorner v Major [2009] UKHL 18 where the court ordered the transfer of a farm into the name of the claimant who had worked on the deceased's farm for 30 years without pay in reliance on oblique assurances made by the deceased that he would inherit it. See B McFarlane and A Robertson 'Apocalypse Averted; Proprietary Estoppel in the House of Lords' [2009] Law Quarterly Review 535; M Dixon, 'Proprietary Estoppel: A Return to Principle?' [2009] Conveyancer and Property Lawyer 260.

55 See Re Pearce [1998] 2 FLR 705 where provision was made for a son who had worked for very low wages on his father's sheep farm.

56 Inheritance (Provision for Family and Dependants) Act 1975, s 4. See Re Salmon [1981] Ch 167 for judicial guidelines on how this discretion is exercised.

57 Solicitors advising such beneficiaries need to be mindful of the taxation implications of such arrangements.

58 Quates v Griffin 239 So 2d 803 (Miss 1970).

59 Trusts of Land and Appointment of Trustees Act 1996, s 14.

60 Administration of Estates Act 1925, s 39(1).

61 S 27(2) of the Law of Property Act 1925, as amended by the Trusts of Land and Appointment of Trustees Act 1996 requires the purchase money to be paid to at least two trustees or a trust corporation. 
developed ${ }^{62}$ which suggested that on the expiry of the limitation period such possessors took their own shares as tenants in common, but acquired the shares of those out of possession as joint tenants. The rationale was that before the estate is distributed, the next-of kin have specific equitable interests as tenants in common in the intestate's estate. Therefore, on the expiry of the limitation period, they would have extinguished the legal title in respect of their own shares, but they would have extinguished the entire title of those out of possession and so would take those shares as joint tenants, as if they were strangers to the title. This approach obviously makes it very difficult to trace the title, as the ruling in Christie v Christie ${ }^{63}$ demonstrates. In that case, a farmer had died intestate and was succeeded by his wife and five children. His wife would have been entitled to a third share in the farm ${ }^{64}$ and each child was entitled to a $2 / 15$ ths share as a tenant in common. The wife and two of his children remained in possession and, when the wife died, the court noted that each child, including those in possession, would have become entitled to a $1 / 5$ th of her third, i.e. another $1 / 15$ th share in the entire farm. On the expiry of the limitation period the two children in possession held 3/15ths each as tenants in common and became entitled to the remaining $9 / 15$ ths of the farm as joint tenants. Section 125(1) of the Succession Act 1965 now clarifies that, where two or more persons are entitled to shares in land forming part of the estate of a deceased person as co-owners and any of them enters into possession, they shall be deemed as between themselves and those who do not enter to have acquired title by possession as joint tenants and not tenants in common, notwithstanding any rule of law to the contrary. This provision treats those entitled to a testate or an intestate share as strangers with no rights in the estate for the purposes of the running of the limitation period.

Section 125 did not apply retrospectively and therefore failed to clarify the legal position in relation to the estate of a person who died before 1 January 1967 (the date the 1965 Act came into force). When this issue was raised in Maher v Maher, ${ }^{65}$ O'Hanlon J acknowledged that the weight of Irish authority was in favour of the view that the nextof-kin remaining in possession should be regarded as tenants in common in relation to their own shares. However, he found the authorities to the contrary more persuasive and noted that the case law on this issue was not consistent. He ruled that where some of the next-of-kin of a deceased owner remain in possession to the exclusion of others, their possession of the entire property is adverse to the claims of the other next-of-kin and the personal representative and, on the expiry of the limitation period, they acquire title as joint tenants. He was not prepared to distinguish between the character of their occupation in relation to the shares claimed by them in their capacity as next-of-kin and the shares of the other next-of-kin which they were in the process of extinguishing. In the Supreme Court decision in Gleeson v Feehan, ${ }^{66}$ Keane J finally put this matter to rest by endorsing the approach taken by O'Hanlon $\mathrm{J}$ in Maher and overruling any contrary authorities. Keane $J$ held that it was contrary to elementary legal principles to regard the next-of-kin of an intestate or those entitled to the residuary estate of a deceased person as being the owners in equity of specific property. They are only entitled to a right, in the nature of a chose in action, to the payment to them of the balance of the estate after the

62 See Ward $v$ Ward (1871) LR 6 Ch App 789; Smith v Savage [1906] 1 IR 469; Christie v Christie [1917] 1 IR 17. For a discussion of this line of authority, see Pearce (n 1); B Spierin and P Fallon, The Succession Act 1965 and Related Legislation: A Commentary 3rd edn (Butterworths 2003) paras 799-801.

63 [1917] 1 IR 17.

64 The land was leasehold which meant that it fell to be distributed according to the rules set out in the Statute of Distributions (Ireland) 1695.

65 [1987] ILRM 542.

66 [1993] 2 IR 113. 
debts have been discharged, a right which can be enforced against the personal representative. It was unnecessary and inappropriate to analyse the ownership of the deceased's estate in terms of who was entitled to the legal estate and who was entitled to the equitable estate. He was satisfied that the possession of one of the next-of-kin and another person following the death of the owner was adverse to the title of the President of the High Court, in whom the entire estate was vested pending the raising of representation. ${ }^{67} \mathrm{On}$ the expiry of the limitation period they acquired title as joint tenants and on the death of one of them, the surviving joint tenant became the sole owner.

Section 125(2) clarifies that sub-s (1) applies even if one of the persons entitled to a share in the deceased's land entered into possession as a personal representative or subsequently took out a grant of representation to the estate of the deceased. ${ }^{68}$ As has already been mentioned, s 123 provides that a personal representative shall not be a trustee for the purposes of the Statute of Limitations 1957.69 Therefore, s 44 of the 1957 Act, which imposes no time limit on actions to recover trust property in the possession of a trustee, does not apply to actions against a personal representative in possession. Also, the definition of a trustee for the purposes of the Statute of Limitations does not include a constructive trustee ${ }^{70}$ and so, in sharp contrast to the English position, ${ }^{71}$ if the court deems the person who took possession to be an executor de son tort ${ }^{72}$ and a constructive trustee for those entitled to the estate, this will not prevent the limitation period from running in that person's favour.

Finally, s 126 of the Succession Act has given rise to confusion and controversy in this area. It replaced s 45 of the 1957 Act which imposed a 12-year limitation period on actions in relation to any entitlements in the estate of a deceased person. The new limitation period is six years unless the right of action was fraudulently concealed, in which case s 71 of the 1957 Act applies. This amendment was clearly designed to speed up the clarification of title to land which forms part of an unadministered estate. However, a lacuna in the application of the new limitation period was highlighted by the

67 This approach contrasts sharply with the approach taken in Earnshaw (n 26).

68 See Spierin and Fallon (n 62) para 804, who point out that, once the estate has been administered and title has been vested in those entitled as tenants in common, s 125 will no longer apply and, where only some take possession for the limitation period, the old difficulties will arise. Those in possession will retain their own shares as tenants in common but the shares of the absent co-owners as joint tenants.

69 Conflicting early authorities had led to confusion over whether a personal representative was an express trustee, as such a trustee was barred from relying on the doctrine pursuant to s 25 of the Real Property Limitation Act 1833: see Re Loughlin [1942] IR 15 and Vaughan v Cottingham [1961 IR 184. Section 2(2)(d) of the Statute of Limitations 1957 clarified the position and this provision was substituted by s 123 of the Succession Act 1965.

70 Statute of Limitations 1957, s 2(2)(a)(i).

71 See James $v$ Williams [2000] Ch 1.

72 The Law Reform Commission has suggested that if a person who takes possession of the deceased's land is deemed to be an executor de son tort he or she will not be able to avail of the running of the limitation period unless he or she fulfils all the duties of the office: see Law Commission, Report on Land Law and Conveyancing Law (7): Positive Covenants over Freehold Land and Other Proposals (LRC 70 2003) para 6.33. It would be quite strange if someone who took out a grant of representation could rely on the doctrine, while a person who did not take out a grant could not. It should be noted that the ruling of Gibson J in Doyle v Foley [1903] 2 IR 95, 100, contradicts the view expressed by the Law Reform Commission on this issue. He stated that unless it was possible to infer an express trust, agency or estoppel from the facts of the case, an executor de son tort is not in a fiduciary relation to a deceased person's estate. He pointed out that in all the authorities cited it was assumed by the court that, in the absence of special circumstances, such an executor could rely on the limitation period. As has already been mentioned, in England, where a personal representative is precluded from relying on the doctrine, it is accepted that an executor de son tort (provided he or she is not a constructive trustee) may benefit from the doctrine. 
High Court decision in Drohan v Drohan ${ }^{73}$ and the subsequent Supreme Court decision in Gleeson $v$ Feehan. ${ }^{74}$ The court, in both instances, ruled that s 126 only applies to actions brought by those entitled to a share in the estate and not to actions brought by the personal representative. Therefore, following an intestate death, if a grant has not yet been extracted and one of the next-of-kin has been in possession, another can extract a grant and rely on the 12-year limitation period to bring an action. It remains unclear whether the next-of-kin are then entitled to insist that the personal representative vests their shares in them, given their limitation period has expired. ${ }^{75}$

In the aftermath of the Gleeson case, practitioners called for reform in this area and the Law Reform Commission in a report published in $2003^{76}$ recommended that a uniform limitation period of 12 years should be applied to claims by beneficiaries and by personal representatives. The Law Reform Commission acknowledged that a return to a 12 -year limitation period in all cases arguably abandons the policy behind s 126, which was to quieten titles as soon as possible after the owner's death and thereby benefit those who remain on to run the family farm or business. However, the recommended approach would lead to greater simplicity and consistency within the general law of adverse possession and remove the anomalies which have arisen since the passing of $\mathrm{s} 126 . .^{77}$ Section 126 provides that the limitation period commences on the date that the right to receive the share or interest accrued and, as this has also been a source of confusion and debate, ${ }^{78}$ the Law Reform Commission recommended legislative clarification that the right of action should be deemed to accrue on the date of death. ${ }^{79}$

These recommendations have yet to be implemented. Although Keating endorses the recommendation for statutory clarification that time begins to run on the date of death, he criticises the primary recommendation for an increase in the limitation period. ${ }^{80} \mathrm{He}$ argues that personal representatives should be brought within the scope of the original amendment. In his opinion, a limitation period of six years is in keeping with the general policy against delay in the administration of estates. In Keating's experience, beneficiaries are not coy when it comes to claiming shares or interests in estates and he notes that any tardiness may be remedied by the citation process. Although he was of the opinion that beneficiaries are rarely undone by sloth, the experience of Land Registry officials seems to suggest otherwise. Over 1000 adverse possession applications are made in relation to registered land on an annual basis ${ }^{81}$ and an internal survey conducted by the Property Registration Authority in 2008 revealed that over 56 per cent of these involved adverse possession between family members, typically in relation to property forming part of an

73 [1984] IR 311.

74 [1993] 2 IR 113.

75 See Spierin and Fallon (n 62) para 811; P R Coughlan 'Limitation of Actions: the Recovery of Land by Personal Representatives' (1991) 13 Dublin University Law Journal 164, 167-68; M Hourigan 'The Running of Time in Succession Law: Gleeson v Feehan and Purcell' (2000) 5(2) Conveyancing and Property Law Journal 34, 36.

76 Law Reform Commission (n 72) ch 6.

77 Ibid para 6.44 .

78 Does the right to receive the share or interest arise on the date of death, when the grant of representation is extracted or once the personal representative takes possession? See Law Reform Commission (n 72) paras 6.14-22.

79 Ibid para 6.27.

80 A Keating, The Law and Practice of Personal Representatives (Round Hall 2004) para 9.19.

81 This level of applications appears to be quite consistent: 1378 s 49 applications were received in 2007 and 1081 applications were received in 2011. 
unadministered estate. 82 This survey also revealed that objections are usually received to such applications and the most frequent objector is someone who claims to be entitled to a share on intestacy or under the will of the deceased registered owner. Of course, once the limitation period has expired, such an objection has no legal basis and will not prevent registration in the absence of another valid ground for objection, for example, proof that the objector continued to engage in acts of possession, that the applicant was not in possession, or was in possession pursuant to an express or an implied licence.

Where only one or some of the next-of-kin enter into or remain in possession following the death of the deceased owner, those out of possession are clearly in a very precarious position as the law currently stands. Any licence agreement which renders the possession consensual and non-adverse should be recorded in writing to avoid future misunderstandings and solicitors consulted by such next-of-kin need to bear in mind the different limitation periods in order to avoid the possibility of a negligence claim. ${ }^{83}$

\section{A critique of the Irish approach}

It is submitted that the role played by the doctrine in updating the ownership of farms following a death on title is no longer significant. ${ }^{84}$ The traditionally casual approach to the administration of estates comprising agricultural land has disappeared during recent decades, probably due to the advent of EU grants. On the death of a farmer, his or her family will wish to ensure that any outstanding entitlements under the single-farm payment scheme are paid into the estate and they will be conscious of the need to transfer the ongoing entitlements. These entitlements pass separate to the land and, in the absence of a specific bequest, they pass to the residuary legatee. The Department of Agriculture requires the submission of a grant of probate or a grant of administration intestate and a valid herd number to secure the transfer of inherited entitlements. Frequently, waivers are also submitted to allow the entitlements to be transferred to the person who is inheriting the farm. ${ }^{85}$ Once the grant has been extracted, it is a fairly simple matter to update the land register which explains why the doctrine is no longer relied on to update farm ownership following a death on title. ${ }^{86}$

The Northern Ireland Law Commission has recently argued that the doctrine of adverse possession continues to perform a useful function in relation to succession to registered farmland ${ }^{87}$ and refers to two recent cases to demonstrate this point: Renaghan $v$ Breen $^{88}$ and Meyler $v$ Ferris. ${ }^{89}$ The commission also maintains that the advent of EU grants, payments or regulations has not changed matters, as generally these schemes do not require the applicant to be the owner of the land. For example, the Nitrates Action

82 This survey is set out in Appendix 2 and discussed in chapter 3, part 2, of the $\mathrm{PhD}$ thesis mentioned above (n 20). The survey illustrates the most common functions performed by the doctrine: namely, the resolution of title defects, updating ownership of property forming part of unadministered estates; tidying up informal transactions; restoring abandoned land to the market and resolving boundary disputes.

83 See Hourigan (n 75) 36.

84 This has been informally confirmed by Irish Land Registry officials.

85 I am grateful to the Inheritance Enquiry Unit of the Department of Agriculture for discussing these requirements with me.

86 While there is no guarantee that the person inheriting the farm will update the register following the issue of the grant, it is likely that obtaining the grant would be viewed as the most onerous part of this process.

87 See Northern Ireland Law Commission, Supplementary Consultation Paper Land Law (NILC 3 2010) para 2.29.

88 [2000] NIJB 174.

89 [2009] NICA 16. 
Programme Regulations (NI) 2006 (No 489) apply to the 'controller' of the land. ${ }^{90}$ As was mentioned above, however, on the death of the original applicant, the administrators of such schemes will generally require proof of a transfer of entitlements and, at least in the case of the single-farm payment, the submission of a grant of probate/ administration intestate. While it may be that the doctrine continues to play a role in this respect in Northern Ireland, in the Republic of Ireland, the evidence indicates that this is no longer the case. It should also be noted that neither of the cases cited by the Northern Ireland Law Commission involved a family member who had gone into possession of a farm many years ago and was now attempting to update the ownership of land forming part of an unadministered estate. In Renaghan v Breen, the disputed land comprised a house and yard which had been the subject matter of an informal transfer to the plaintiff's great-grandfather dating back to the 1880s. It had subsequently passed down through the family line to the plaintiff. The court was satisfied that adverse possession had been established against the registered owner by the cumulative adverse possession of the plaintiff's predecessors or in the alternative by the plaintiff's 12 years' adverse possession since 1975. Although the disputed land in Meyler $v$ Ferris was a farm, the paper title was completely up-to-date until the death of the owner, Bridie Ferris, in 2005. She had left the land to her niece, but her nephew claimed in these proceedings to have acquired title to the farm by adverse possession. The court was satisfied, however, that any acts of adverse possession by the defendant had only begun in 2001 and, therefore, the limitation period had not expired. ${ }^{91}$ It submitted, therefore, that these authorities do not demonstrate that the doctrine continues to play an important role in updating the ownership of farms forming part of an unadministered estate.

If this peculiarly agricultural justification for the doctrine has become obsolete, it is necessary to consider whether adverse possession should continue to play the same role in the context of unadministered estates. Is it fair to allow the occupying sibling to extinguish the rights of those out of possession? Although it is difficult to make generalisations in this area, it could be argued that the moral entitlement of an applicant who has entered or remained in possession of the family home or a residential investment property following the death of a parent is not as strong as that of a child who had been raised to take over a farm and perhaps forgone an education and adequate pay during the lifetime of the parent. It is also easy to imagine a situation where absent members of the family were content to allow a sibling to continue to occupy a property, but failed to appreciate that their interests were in danger of being extinguished by neglecting to formalise the arrangement. The fact that family members frequently object to s 49 applications reflects the counter-intuitive nature of the law on this issue. The potential for misunderstanding renders absent members extremely vulnerable, an argument which has been made to justify the English position which precludes adverse possession in such circumstances. ${ }^{92}$

90 It could be argued that the most straightforward way for a farmer to demonstrate control of the land (assuming he or she is not in occupation under a lease or a licence) is to submit proof that he or she is the current registered owner, although admittedly those administering such schemes may not insist on this: see Meyler $v$ Ferris ibid (the defendant had applied for and received certain subsidies in relation to the land for a few years until the niece who had inherited the land objected that he did not have permission to claim them).

91 The facts of this case bear some resemblance to those of Gunning v Sherry [2012] IEHC 88. In Gunning, the owner of a cottage had made a will leaving it to his wife and two daughters. After he died, one of the daughters attempted to rely on the doctrine of adverse possession against her mother and sister, but the court held that she had failed to demonstrate anything approaching the requisite limitation period.

92 See Miller (n 8). 
At the beginning of this paper, the Law Reform Commission's proposals for the reform of the Irish law on adverse possession were mentioned. These reforms required an applicant seeking to establish title by adverse possession to make a court application and purported to limit the doctrine's operation so that it would no longer operate unfairly. ${ }^{93}$ Although these recommendations appear to have been abandoned, they are still of interest as the Law Reform Commission envisaged a continuing role for the doctrine in the context of unadministered estates. The court would be permitted to grant a vesting order if the adverse possession application related to land comprised in a deceased person's estate and it was reasonable to assume that an order in favour of the applicant would accord with the deceased's wishes. ${ }^{94}$ This reform seems to be designed to preserve the role played by the doctrine in effecting the transfer of a farm forming part of an unadministered estate to a child who remained in possession following the intestate death of a farmer. However, the introduction of an approach which appears to require the court to guess at the subjective views of the deceased owner seems unwise, especially when the doctrine of proprietary estoppel provides a much more stable basis for the grant of a remedy in such circumstances 95 and also allows the court more flexibility in its response. ${ }^{96}$ If the child can prove an intention to create legal relations, consideration and part performance, it may also be possible to prove that the deceased entered into a contract to leave a particular property to him or her by will. In McCarron v McCarron, ${ }^{97}$ the Supreme Court was satisfied that the farmer had entered into a contract to devise the farm to the plaintiff (his first cousin once removed) in consideration of the free labour that the plaintiff had provided on the farm and would continue to provide during the farmer's lifetime. ${ }^{98}$ The court ordered specific performance of that contract, ${ }^{99}$ but Murphy J noted that the plaintiff may also have been entitled to a remedy pursuant to the doctrine of proprietary estoppel. It is important to note, however, that recent case law 100 has treated such causes of action as subsisting against the deceased on his or her date of death and therefore subject to s 9(2)(b) of the Civil Liability Act 1961 which imposes a

93 Law Reform Commission (n 1) 327-32.

94 The court would also have the option of ordering the payment of compensation. The requirement for a court application and the possibility of compensation were criticised by the Law Society of Ireland as they would increase costs and clog up the courts unnecessarily given that the Land Registry procedure has been operating successfully to date.

95 See Smyth v Halpin [1997] 2 ILRM 38 where in response to his father's assurance that the family home would be his after his mother's death and, at his father's suggestion, the son built an extension to the home at his own expense. When his father left the home to one of his daughters instead, the court ordered a conveyance of the house to the son pursuant to the doctrine of proprietary estoppel.

96 In some circumstances, conferring a right of residence or awarding compensation may be more appropriate than an outright transfer of ownership. See H Delany, Equity and the Law of Trusts in Ireland 4th edn (Round Hall 2007) 728-38.

97 [1997] 2 ILRM 349.

98 The court commented that in some parts of Ireland, particularly rural areas, a meeting of minds can be achieved without as detailed a discussion as might be necessary elsewhere and noted how the evidence of the plaintiff evinced a natural courtesy (which John Millington Synge associated with the west of Ireland) which often results in an unwillingness to pursue discussion to a logical and perhaps harshly expressed commercial conclusion.

99 Such a remedy will not usually be available in England and Wales as contracts for the sale of land entered into after 26 September 1989 are void unless they are in writing; see s 2(1) of the Law Reform (Miscellaneous Provisions) Act 1989.

100 In the Matter of the Estate of F Deceased, S $1 v$ PR 1 and PR 2 [2013] IEHC 407; Prendergast v McLaughlin [2009] IEHC 250; Corrigan v Martin (HC, 13 March 2006). See also, A Keating, 'The Application of s 9(2)(b) of the Civil Liability Act 1961 to Equitable Causes of Action Against Estates of Deceased Persons' (2010) 15(2) Conveyancing and Property Law Journal 37. 
limitation period of two years from the date of death ${ }^{101}$ to bring proceedings against the deceased's estate.

It should be noted that a child also has the option of bringing an application pursuant to s 117 of the Succession Act 1965,102 although such an application must be brought within six months of the extraction of the grant ${ }^{103}$ and is unavailable if the parent dies intestate. ${ }^{104}$ If the court is of the opinion that the testator has failed in his or her moral duty to make proper provision for the child in accordance with his or her means, whether by will or otherwise, it may order that just provision be made for the child out of the estate. ${ }^{105}$ In assessing the extent of that moral duty, the court will have regard to special circumstances, such as where 'a child is induced to believe that by . . . working on a farm, he may ultimately become the owner of it, thereby causing him to shape his upbringing, training and life accordingly.' 106

McDonald v Norris ${ }^{107}$ concerned a s 117 application by a son who had left school early to look after the farm after his father had an accident and had worked for minimal recompense for over 20 years. The relationship between father and son had been very bad since the son's marriage and, at one point, the son was imprisoned for refusing to comply with an order for possession of the lands which his father had obtained against him. While the son was in prison, the father sold some of the land and transferred another portion to the applicant's younger brother. The Supreme Court acknowledged the applicant's bad behaviour towards his father, but felt that it should be considered in the context of his father's reaction to his marriage. His bad behaviour diminished the extent of the father's moral obligation, but did not extinguish it. The court ordered the transfer of the remaining lands to the son, on condition that he paid a sum of money to his cousin (the father's intended beneficiary). $A v C$ and $D^{108}$ concerned an application by a son who had received a third share in the proceeds of sale of one parcel of land, $€ 40,000$, a site and some machinery. The deceased's grand plan was to leave a farm to each of his three sons, but difficult economic conditions intervened and when he died he only owned two

101 Or the period of limitation prescribed by the Statute of Limitations 1957 or any other limitation enactment, whichever expires earlier. No special shortened limitation period is imposed in relation to subsisting claims against an estate in England; see the Law Reform (Miscellaneous Provisions) Act 1934.

102 The Law Reform Commission has recently sought views on whether s 117 of the Succession Act 1965 should be repealed, retained as it is, or amended; see Law Reform Commission, Issues Paper on Section 117 of the Succession Act 1965 (LRC IP 92016 ) para 1.5.

103 S 117(6) of the Succession Act 1965 originally set a time limit of 12 months, but it was reduced to six months by s 46 of the Family Law (Divorce) Act 1996. This time limit is strictly applied (see MPD v MD [1981] ILRM 179) and the personal representatives are under no obligation to inform the testator's children of their right to bring a s 117 application (see Rojack $v$ Taylor and Buchalter [2005] IEHC 28). It was recently clarified that the six-month limitation period does not run from the issue of an ad litem grant: see In the Matter of the Estate of F deceased (n 100). The Law Reform Commission has recently sought views on whether s 117(6) should be amended to extend this time limit and to clarify that the limitation period begins to run from the date of death or some other date; see Law Reform Commission (n 102) paras 3.5 and 4.3.

104 The deceased must die wholly or partly testate: see the 1965 Act, s 109. In RG v PSG (HC, 20 November 1981), Carroll J held that the deceased had died testate for the purposes of s 109 even though the will was wholly inoperative at the date of his death. The Law Reform Commission has recently sought views on whether s 117 should be extended to claims by children of parents who die intestate; see Law Reform Commission (n 102) para 2.3.

105 See J C Brady, Succession Law in Ireland 2nd edn (Butterworths 1995) paras 7.48-79; Speirin and Fallon, (n 62) paras 695-745; F de Londras, Principles of Irish Property Law 2nd edn (Clarus Press 2011) paras 16.69-96.

106 See Re ABC deceased; XC and Others $v$ RT and Another (HC, 2 April 2003). See MH and NMcG v NM and CM [1983] ILRM 519.

107 [2000] 1 ILRM 382.

108 [2007] IEHC 120. 
farms. The applicant had been dependent on the deceased for many years to provide him with a farming livelihood and a residence for his family which he would now lose. The court was satisfied that the deceased had failed in his moral duty. An order for the transfer of either of the farms to the applicant would leave the deceased's remaining children inadequately provided for and, instead, the court ordered that the sum of $€ 750,000$ be substituted for the applicant's testamentary legacy of $€ 40,000 .{ }^{109}$

Hourican notes that, if a s 117 application or proprietary estoppel claim seems unlikely to succeed, the child may bring a claim, in the alternative, for payment on a quantum meruit basis for works done or services rendered by the plaintiff for and at the request of the deceased. ${ }^{110}$ It is clear, therefore, that a child who feels hard done by as a result of the intestacy rules or the provision made by a parent's will may have access to a number of remedies which allow the court the flexibility to specifically address the injustice and limit the impact of any order on the other beneficiaries. To avail of any of these remedies, the child must be cognisant of the relevant limitation periods as such actions become statute-barred within a short period of time. The reason for these special shortened limitation periods following a death is clear. As Fennelly J stated in Corrigan v Martin:

One relevant consideration is that those charged as executors or administrators of estates of deceased persons are entitled and, indeed, bound to carry out their tasks with reasonable expedition and that creditors of the estate and, ultimately, the beneficiaries are entitled to have the estate administered within a reasonable time. I believe the Oireachtas deliberately chose to impose a short but fair time limit on claims so that these desirable objectives would be achieved. ${ }^{111}$

\section{Conclusion}

Adverse possession is a crude mechanism to rely on to resolve the disputes which can arise between beneficiaries with an entitlement to land following a death on title. It results in the automatic transfer of ownership to the possessor without any consideration of the circumstances of the other beneficiaries or their vulnerability to a claim when a family member goes into possession. It is submitted that these beneficiaries are in need of additional protection and this paper demonstrates that adequate alternative remedies exist to protect a beneficiary with a moral claim.

It would not be appropriate to emulate the English law which absolutely precludes adverse possession between co-owners, as there is no appetite in Ireland to impose a trust of land on co-owners. ${ }^{112}$ Neither would such reform be necessary to achieve the desired result. It is submitted that the doctrine of adverse possession should continue to operate

109 The court rejected the applicant's claim that he had acquired title to the residence and surrounding lands by adverse possession as the court was satisfied that he had been present by the licence of the deceased. The court also rejected his claim for a remedy pursuant to the doctrine of proprietary estoppel on the basis of the improvements which he had carried out to the residence, as the court could find no evidence of an assurance by the deceased that the residence would be his.

110 M Hourican, 'Section 117 Claims: Practice and Procedure and Matters to Bear in Mind' (2001) 6(3) Conveyancing and Property Law Journal 62. Note that, in Coleman v Mullen [2011] IEHC 179, the court emphasised that, if the services were rendered on a voluntary basis and without an intention to create legal relations, a quantum meruit claim must fail.

111 Corrigan v Martin (HC March 13 2006) p 6 of transcript, endorsing the views expressed by O'Higgins CJ in Moynihan v Greensmyth [1977] IR 55.

112 See Law Reform Commission (n 72) para 5.05; Law Reform Commission, Consultation Paper on Reform and Modernisation of Land Law and Conveyancing Law (LRC CP 34 2004) para 6.03; Law Reform Commission (n 102) para 3.5 . 
between co-owners, but, at the end of the limitation period, a veto should be conferred on the co-owners out of possession. This would enable land to be brought back on to the market in the event that certain co-owners had abandoned their interests, but would also confer added protection on vulnerable co-owners who had assumed that their interests were not in danger of being extinguished. The impact would be similar to a return to the law on non-adverse possession, which required proof of an ouster between co-owners, ${ }^{113}$ although the veto approach would be much more straightforward to apply.

As has been argued elsewhere, registration principles should not limit the protective scope of any qualified veto system of adverse possession introduced in Ireland. ${ }^{114}$ Therefore, following a death on title, the veto could easily be extended to any personal representative appointed and any beneficiaries entitled under the will or the rules on intestacy. ${ }^{115}$ Where land was being adversely possessed by a stranger to the title before the death of the owner, this approach, in contrast to the English one, would confer added protection on his or her successors during the period following the death of the owner while the estate remains unadministered and the register is out-of-date. If one successor makes an adverse possession application against other successors with entitlements under an unadministered estate, those out of possession would be able to veto the application. If they fail to exercise their veto, because they have no objection to the registration of the applicant as owner or they have abandoned their interests, the application would proceed. Also, the personal representative's veto would not be effective against an adverse possessor solely entitled under the deceased owner's will or the rules governing intestacies. Therefore, the doctrine would continue to play a very limited role where the unadministered estate involved abandoned interests or an informal transmission.

If the veto is exercised, the dispute will have to be resolved between the successors. The adverse possessor may have to negotiate releases from the objectors if he or she wishes to be registered as the sole owner and, if these releases are not forthcoming, and the beneficiaries are not prepared to be registered as co-owners, the property would have to be sold in the course of administration and the proceeds distributed amongst them. ${ }^{116}$ It is important to bear in mind that a claim based on the doctrine of proprietary estoppel or s 117 of the 1965 Act would also be available in the immediate aftermath of the deceased's death. However, restricting the operation of the doctrine of adverse possession in this particular context would render it necessary to ensure that the alternative remedies available are adequate. Therefore, it is submitted that, in line with previous recommendations which have been made in this regard, s 117 of the Succession Act should be extended to intestate deaths and the court should be given a discretion to extend the deadline for bringing such an application. ${ }^{117}$

113 See above (n 9).

114 See Woods (n 20), chs 2 and 9, for further discussion.

115 Where such information is not available, notice could be served by posting site notices or advertising in newspapers.

116 Pursuant to s 50 of the Succession Act 1965.

117 See the Law Reform Commission, Report on Land Law and Conveyancing Law (LRC 30 1989) 21-24; Law Reform Commission (n 102) paras 2.3 and 3.5. See also, E Storan, 'Section 117: Another Means for the Courts to Rewrite a Will?’ (2006) 11(4) Conveyancing and Property Law Journal 82a. Similarly, it may be necessary to revisit the shortened limitation period imposed by s 9(2)(b) of the Civil Liability Act 1961 in relation to subsisting claims against an estate. 